\title{
PENGEMBANGAN PEMBELAJARAN BERBASIS WEB PADA MATERI TINGKAT BUNGA SEDERHANA DAN TINGKAT BUNGA MAJEMUK
}

\author{
Supriono K. Bulukaya ${ }^{1 *}$, Yamin Ismail ${ }^{2}$, Siti Zakiyah ${ }^{3}$ \\ 1,2,3 Jurusan Matematika, Fakultas MIPA, Universitas Negeri Gorontalo, Bone Bolango, Gorontalo, Indonesia \\ *Penulis Korespondensi. Email: suprionok.bulukaya@gmail.com
}

\begin{abstract}
Abstrak
Penilitian ini bertujuan untuk menghasilkan media pembelajaran matematika yang baik untuk Materi Tingkat Bunga Sederhana dan Tingkat Bunga Majemuk serta mengetahui respon dan peran media terhadap mahasiswa. Jenis penelitian yang dilakukan adalah penelitian pengembangan yang diawali dengan pengembangan media berbasis web. Model pengembangan yang digunakan adalah Model pengembangan Four-D (4D) yang dimodifikasi yaitu tahap pendefinisian, tahap perancangan, dan tahap pengembangan. Subjek penelitian adalah mahasiswa program studi matematika Universitas Negeri Gorontalo. Hasil penelitian menunjukan kualitas media berdasarkan hasil validasi ahli media adalah sangat valid. Mahasiswa memberikan respon positif. Hal ini menunjukkan bahwa media pembelajaran dapat digunakan dalam proses pembelajaran dan media pembelajaran memiliki peran dalam meningkatkan pemahaman mahasiswa.n masalah siswa dapat lebih aktif dalam pembelajaran jarak jauh yang dilaksanakan.
\end{abstract}

Kata Kunci: Pengembangan Pembelajaran; Four-D; Tingkat Bunga Sederhana; Tingkat Bunga Majemuk

\begin{abstract}
This research aims to produce good mathematics learning media for Simple Interest Rate and Compound Interest Rates and find out the media's response and role towards students. This type of research is development research that begins with the development of web-based media. The development model used is a modified Four-D (4D) development model, namely the definition stage, the design stage, and the development stage. The research subjects were students of the Gorontalo State University mathematics study program. The results showed that the quality of the media based on the results of the validation by media experts was very valid. Students give a positive response. This shows that learning media can be used in the learning process, and learning media can increase student understanding.
\end{abstract}

Keywords: Learning Development; Four-D; Simple Interest Rate and Compound Interest Rate

\section{Pendahuluan}

Perkembangan zona industri dan teknologi sudah masuk 4.0 dimana pemanfaatannya sudah berkembang ke berbagai aspek dan bidang aktifitas masyarakat salah satunya di bidang pendidikan. era pendidikan 4.0 menuntut adanya pemanfaatan teknologi digital dalam proses pembelajaran atau lebih dikenal dengan cyber system. Undang-undang No. 20, tahun 2003 pasal 3 menyebutkan pendidikan nasional berfungsi mengembangkan kemampuan dan membentuk watak serta peradaban bangsa, yang bermartabat dalam rangka mencerdaskan kehidupan bangsa, bertujuan untuk berkembangnya potensi peserta didik agar menjadi manusia yang beriman dan bertakwa, berakhlak mulia, sehat, berilmu, cakap, kreatif, mandiri, dan menjadi warga negara yang demokratis serta bertanggung jawab. Pendidikan merupakan salah satu cara untuk mengasah potensi yang ada dalam 
diri [1]. Pembelajaran matematika adalah suatu proses interaksi belajar mengajar pelajaran matematika yang dilakukan antara peserta didik dan pengajar yang mana, proses tersebut merupakan sebagai suatu sarana atau wadah yang berfungsi untuk mempermudah berfikir di dalam ilmu atau konsep-konsep abstrak [2].

Matematika merupakan salah satu ilmu pengetahuan yang sangat penting bagi kehidupan. Peranan matematika sangat berpengaruh dalam kegiatan pembelajaran untuk meningkatkan prestasi belajar mahasiswa. Untuk mencapai pembelajaran matematika yang mudah dan menyenangkan harus terus dikembangkan dengan berbagai strategi, model, metode, dan pelibatan media pembelajaran yang membutuhkan kreatifitas dosen. Bagi seorang mahasiswa keberhasilan mempelajari matematika akan membuka pintu karir yang cemerlang di tingkat selanjutnya, karena matematika dapat menunjang pengambilan keputusan yang tepat, mampu berkompetisi di bidang ekonomi dan teknologi, membekali peserta didik dengan kemampuan berpikir logis, inovatif dan kreatif serta melatih kemampuan bekerja sama.

Namun pada kenyataannya, Belajar matematika sering kali dianggap sulit, karena kesulitan mahasiswa mempelajari matematika disebabkan oleh sifatnya yang membutuhkan kemampuan berpikir logis dan terurut. oleh karena itu diperlukan cara tersendiri untuk mempelajarinya dengan mengetahui bahwa matematika Memiliki karakter dan kekhasan tersendiri, maka dosen diharapkan mampu mengupayakan berbagai cara-cara yang sesuai pada kegiatan pembelajarannya agar tujuan pembelajaran dapat tercapai salah satunya adalah dengan pembelajaran berbasis web. Dari hasil pengamatan, mahasiswa saat ini sangat tertarik dengan teknologi informatika dan perkebangan teknologi sudah semakin pesat. Akan tetapi dalam proses belajar mengajar dikampus kurangnya pemanfaatan teknologi pembelajaran terutama yang berbasis web. Ini menyebabkan kurang efektifnya penyampaian materi dalam proses belajar mengajar di kampus yang tuntutan pembelajaran banyak dan waktu pembelajaran begitu padat. semua ini berpengaruh pada motivasi belajar mahasiswa. Motivasi memiliki peranan penting dalam peningkatan hasil belajar matematika karena mahasiswa yang termotivasi dapat menggunakan proses kognitif yang lebih tinggi untuk belajar, mempelajari, dan menguasai materi yang diberikan.

Salah satu aspek yang harus diperhatikan dalam memilih dan menggunakan pembelajaran yang tepat adalah tentang modalitas belajar anak. Modalitas belajar merupakan potensi dasar atau kecenderungan yang dimiliki anak. Dengan modalitas belajar mahasiswa yang variatif, seharusnya pemilihan pembelajaran dari seorang dosen tidak hanya terfokus pada salah satu modalitas saja, seperti yang pada umumnya terjadi. Jika ditinjau dari hal tersebut, maka seorang dosen perlu mengombinasikan berbagai media dalam menyampaikan pesan sehingga pembelajaran akan lebih optimal [3].

Salah satu upaya pendorong motivasi, modalitas dan hasil belajar mahasiswa lebih optimal adalah pembelajaran berbasis teknologi web. pembelajaran berbasis web yang popular dengan sebutan web-based learning (WBL) atau kadang juga disebut Web Based Education (WBE) adalah sistem pembelajaran berbasis web. Dikatakan berbasis web karena dalam pembelajaran tersebut pemberian materi diberikan secara klasikal atau konvensional dikelas, tetapi pemberian tugas dan beserta pengumpulannya dan seluruh kegiatan pendalaman materi dilakukan melalui web [4].

Pembelajaran berbasis web merupakan suatu pembelajaran yang memanfaatkan teknologi internet tanpa ada batasan ruang dan waktu. Pembelajaran ini bukan sekedar meletakkan materi pada web kemudian dapat diakses melalui komputer atau smartphone, dan web tidak semata-mata digunakan untuk alternatif pengganti kertas untuk menyimpan dokumen atau informasi. Pembelajaran berbasis web tersebut memiliki beberapa kegunaan dan keuntungan, diantaranya pembelajaran berbasis web dapat menurunkan suasana yang statis dan dapat menciptakan proses pembelajaran yang efektif, menarik, interaktif, dan dapat membangkitkan motivasi belajar peserta didik [5]. 
Selain itu dalam membangkitkan motivasi belajar mahasiswa bisa juga dengan materi pembelajaran yang berkaitan dengan dunia nyata atau yang sering terjadi dalam kehidupan seharihari. Salah satu mata kuliah yang berkaitan dengan kehidupan sehari-hari adalah matematika keuangan. Untuk mengurangi permasalahan yang sering kita dapati seperti diatas, maka peneliti tertarik untuk mengembangkan sistem pembelajaran dengan merancang sebuah pembelajaran berbasis web melalui judul "Pengembangan Pembelajaran Berbasis Web Pada Materi Tingkat Bunga Sederhana Dan Tingkat Bunga Majemuk".

\section{Metode}

Metode penelitian yang digunakan dalam makalah ini adalah penelitian pengembangan dengan pendekatan deskriptif yang berorientasi pada pengembangan produk. Penelitian dilakukan untuk menghasilkan produk tertentu dan menguji keefektifan produk tersebut. Desain penelitian pengembangan pada makalah ini mengacu pada model Four-D, yang terdiri dari 4 tahap pengembangan yaitu Define, Design, Develop, dan Disseminate atau diadaptasikan menjadi model 4P, yaitu pendefinisian, perancangan, pengembangan, dan penyebaran [6].

\subsection{Prosedur Pengembangan}

Dalam implementasinya pada makalah ini, pengembangan model dilakukan hanya menggunakan 3 tahapan, yaitu pendefinisian, perancangan dam pengembangan. Desain 3 tahapan ini mengacu dengan langkah-langkah:

1. Menyederhanakan tahapan pengembangan dari 4 tahap yaitu menjadi 3 tahap yaitu tahap pendefinisian (define), perancangan (design), pengembangan (develop) dengan menghilangkan tahap penyebaran (Disseminate). Hal ini dilakukan karena tujuan penelitian ini adalah hanya mengembangkan media pembelajaran.

2. Pada tahap perancangan (Design), bagian penyusunan tes dihilangkan, karena dalam pengembangan ini hanya bertujuan menghasilkan media pembelajaran berbasis web tanpa melihat tes hasil belajar mahasiswa yang diperoleh dari pembelajaran dengan menggunakan media pembelajaran berbasis web yang dilakukan.

3. Analisis konsep dan analisis tugas yang awalnya paralel, diubah menjadi berurutan dari analisis konsep ke analisis tugas. Hal ini dilakukan karena dalam pembelajaran matematika materinya terstruktur sehingga urutan tugas bergantung dari urutan konsep.

4. Isitilah analisis konsep diganti dengan analisis materi. Hal ini dilakukan karena yang dikembangkan adalah media pembelajaran. Materi yang dimaksud memiliki cakupan yang lebih luas daripada konsep. Dari satu materi terdapat beberapa konsep didalamnya.

Diagram alir pengembangan media pembelajaran menggunakan model 4-D yang telah dimodifikasi ditampilkan pada Gambar 1. Sementara itu, tahapan-tahapan pengembangan diuraikan sebagai berikut.

\subsubsection{Tahap Pendefinisian (Define)}

Tujuan dari tahap ini adalah menetapkan dan mendefinisikan syarat-syarat pembelajaran. Pada tahap ini dilakukan analisis tujuan dalam batasan materi pelajaran yang akan dikembangkan media webnya. Ada lima langkah pokok dalam tahap pendefinisian, yaitu:

\section{a. Analisis awal-akhir}

Langkah ini digunakan untuk mendapatkan masalah mendasar yang dihadapi pada proses pembelajaran dalam meningkatkan hasil belajar mahasiswa. 


\section{b. Analisis mahasiswa}

Tujuan analisis mahasiswa adalah menelaah tentang karakteristik mahasiswa sebagai gambaran untuk mendesain dan pengembangan multimedia pembelajaran.

c. Analisis tugas

Analisis tugas bertujuan untuk mengidentifikasi keterampilan utama dan menganalisisnya ke dalam suatu kerangka sub keterampilan.

d. Analisis konsep

Analisis ini bertujuan untuk mengidentifikasikan, merinci dan menyusun secara sistematis konsep utama pada materi tingkat bunga sederhana dan tingkat bunga majemuk yang akan dipelajari mahasiswa.

e. Analisis tujuan pembelajaran

Analisis ini merupakan perumusan tujuan pembelajaran berdasarkan indikator dan penjabarannya berdasarkan hasil analisis materi dan analisis tugas yang telah disusun sebelumnya.

\subsubsection{Tahap Perancangan (Design)}

a. Pemilihan media

Pemilihan media berkenaan dengan penentuan media yang tepat untuk menyajikan materi pembelajaran.

b. Pemilihan format

Pemilihan format disesuaikan dengan faktor-faktor yang telah dijabarkan pada tujuan pembelajaran.

c. Perancangan awal

Perancangan awal merupakan perancangan media pembelajaran yang dirancang yang akan melibatkan aktivitas dosen dan mahasiswa.

\subsubsection{Tahap Pengembangan (Develop)}

Tahap ini bertujuan untuk menghasilkan multimedia pembelajaran yang telah direvisi berdasarkan masukan para ahli, selanjutnya gunakan dalam uji coba di kelas yang menjadi subjek penelitian.

\section{a. Validasi ahli}

Validasi ahli dimaksudkan untuk memperoleh saran perbaikan. Beberapa ahli diminta untuk mengevaluasi media pembelajaran. Berdasarkan saran mereka, media pembelajaran diperbaiki sehingga lebih tepat, efektif, bermanfaat dan berkualitas tinggi sehingga dapat digunakan dalam proses pembelajaran.

b. Uji coba

Uji coba dilakukan untuk memperoleh masukan langsung mahasiswa terhadap media pembelajaran yang telah disusun. 


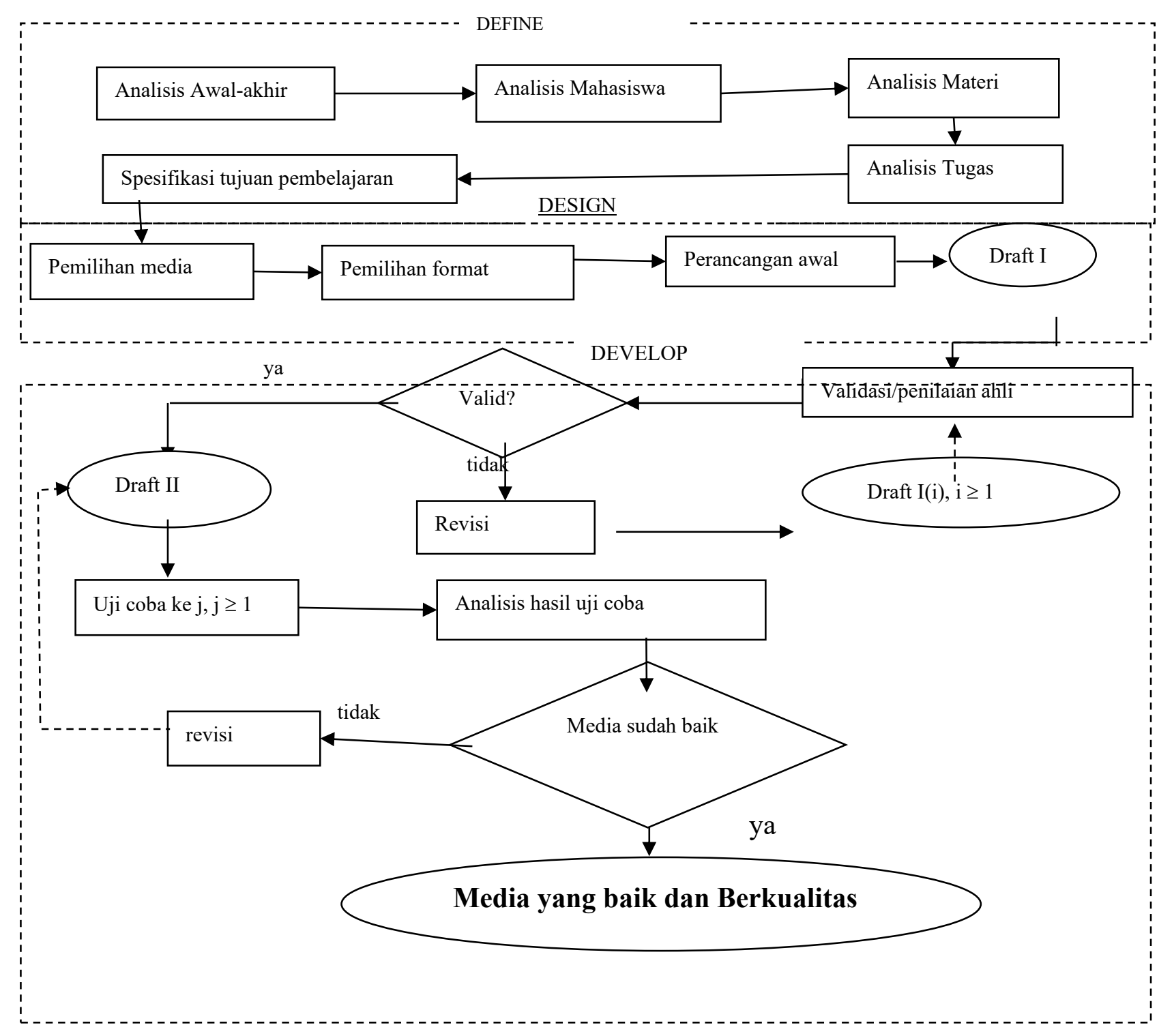

Keterangan
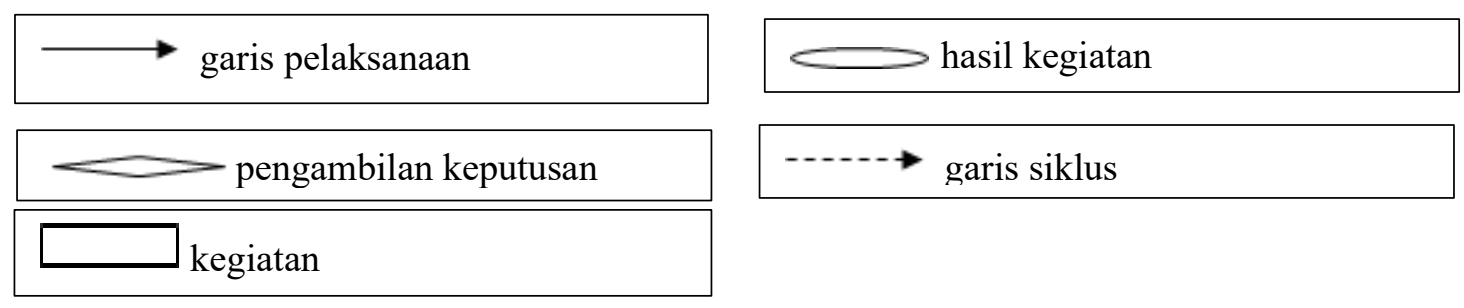

Gambar 1. Alur pengembangan media pembelajaran menggunakan model 4-D

\subsection{Teknik Analisis}

Selanjutnya, teknik analisis data yang digunakan dalam penelitian ini adalah analisis deskriptif. Analisis data yang dilakukan terdiri atas analisis hasil validasi dan analisis respon mahasiswa.

\subsubsection{Analisis Hasil Validasi}

Pada masing-masing lembar validasi media pembelajaran materi tingkat bunga sederhana dan tingkat bunga majemuk, validator menuliskan penilaian terhadap media pembelajaran. Penilaian terdiri 5 kategori, yaitu tidak baik (nilai 1), kurang baik (nilai 2), cukup baik (nilai 3), baik (nilai 4) 
dan sangat baik (nilai 5) Media pembelajaran berbasis web dapat digunakan jika minimal validator memberikan penilaian dengan kategori baik. Menggunakan indeks validitas, diantaranya dengan indeks yang diusulkan oleh Aiken sebagai berikut,

$$
V=\frac{\Sigma s}{N(c-1)} \text { dimana } s=r-i
$$

Rata-rata keseluruhan adalah

Keterangan:

$$
\frac{\sum_{i=1}^{n} V i}{n}
$$

$\mathrm{V} \quad$ : Validasi isi

$\mathrm{r} \quad$ : Rating penilaian

$\mathrm{N}$ : Jumlah penilaian/responden

i : Rating penilai kategori terendah 1

c : Rating tertinggi yaitu 5

Adapun skala penilaian validasi mengacu pada Tabel 1.

Tabel 1. Kriteria Respon Positif Mahasiswa

\begin{tabular}{cc}
\hline Persentase $(\%)$ & Interpretasi \\
\hline $85 \% \mathrm{R} 100 \%$ & Sangat positif \\
$70 \% \mathrm{R}<85 \%$ & Positif \\
$50 \% \mathrm{R}<70 \%$ & Kurang positif \\
$0 \% \mathrm{R}<50 \%$ & Tidak positif \\
\hline
\end{tabular}

\subsubsection{Analisis respon mahasiswa}

Data respon mahasiswa yang diperoleh melalui angket dianalisis berdasarkan persentase. Persentase tiap respon dihitung dengan cara jumlah respon mahsiswa tiap aspek yang muncul dibagi dengan jumlah seluruh mahasiswa dikali $100 \%$. Persentase tersebut dikonversikan dengan kategori yang diadopsi sebagaimana ditampilkan pada Tabel 2.

Tabel 2. Kriteria Validasi Ahli

\begin{tabular}{cc}
\hline Persentase $(\%)$ & Interpretasi \\
\hline $0,81-1,00$ & Sangat sesuai \\
$0,61-0,80$ & Sesuai \\
$0,41-0,60$ & Cukup sesuai \\
$0,21-0,40$ & Kurang sesuai \\
$0,00-0,21$ & Tidak sesuai \\
\hline
\end{tabular}

\section{Hasil dan Pembahasan}

Hasil dan pembahasan penelitian diuraikan menyesuaikan dengan tahapan-tahapan pengembangan pembelajaran yang mengacu pada model pengembangan 4D. Dalam penelitian ini, tahapan pengembangan hanya dilakukan sampai pada tahap ketiga, yaitu tahap pengembangan. 


\subsection{Tahap Pendefinisian}

\subsubsection{Analisis awal-akhir}

Aktivitas yang dilakukan adalah mengidentifikasi masalah mendasar yang dihadapi dosen mata kuliah matematika keuangan dalam proses pembelajaran dan untuk mengetahui karakteristik mahasiswa. Adapun yang dilakukan pada kegiatan ini adalah wawancara kepada dosen mata kuliah matematika keuangan. Dari wawancara tersebut diperoleh informasi bahwa proses pembelajaran matematika di kelas menggunakan media berupa siat,zoom,google meet, dan google form. Hal ini berpengaruh pada proses belajar mahasiswa yang dimana mereka kurang paham dan bingung terutama dalam pengiriman tugas melalui siat yang menggunakan waktu. Hal ini mengakibatkan sebagian mahasiswa terlambat dalam mengirimkan tugasnya.

Berdasarkan wawancara tersebut, maka diperlukan suatu Media pembelajaran yang dapat membantu dosen dalam melaksanakan pembelajaran ini baik karena dapat membuat mahasiswa lebih aktif dan tampilannya pun lebih menarik sehingga mahasiswa dapat mengikuti proses pembelajaran dengan baik dan dapat mencapai tujuan pembelajaran yang diinginkan.

\subsubsection{Analisis mahasiswa}

Berdasarkan hasil wawancara didapatkan bahwa mahasiswa sering menggunakan alat bantu handphone untuk mengakses internet dalam proses pembelajaran, selain itu mereka lebih senang belajar menggunakan computer. Akan tetapi dalam pengoperasian media dalam mengumpulkan tugas ataupun ujian mereka sering terkendala dalam penentuan batas waktu pengumpulannya yang mengakibatkan beberapa mahasiswa tidak dapat mengumpulkan hasil tugas atau ujiannya, maka dari itu dibutuhkan sebuah sebuah media pembelajaran yang dapat membuat mahasiswa mengumpulkan atau mengerjakan tugas yang memiliki pemberitahuan sisa berapa lama lagi waktu pengerjaan tugas atau ujian.

\subsubsection{Analisis materi}

Analisis materi bertujuan untuk menyusun konsep-konsep dalam sub materi yang akan dipelajari oleh mahasiswa. Sub materi yang diajarkan mengacu pada capaian pembelajaran untuk program studi matematika. Analisis materi tingkat bunga sederhana dan tingkat bunga majemuk diberikan pada Gambar 2.

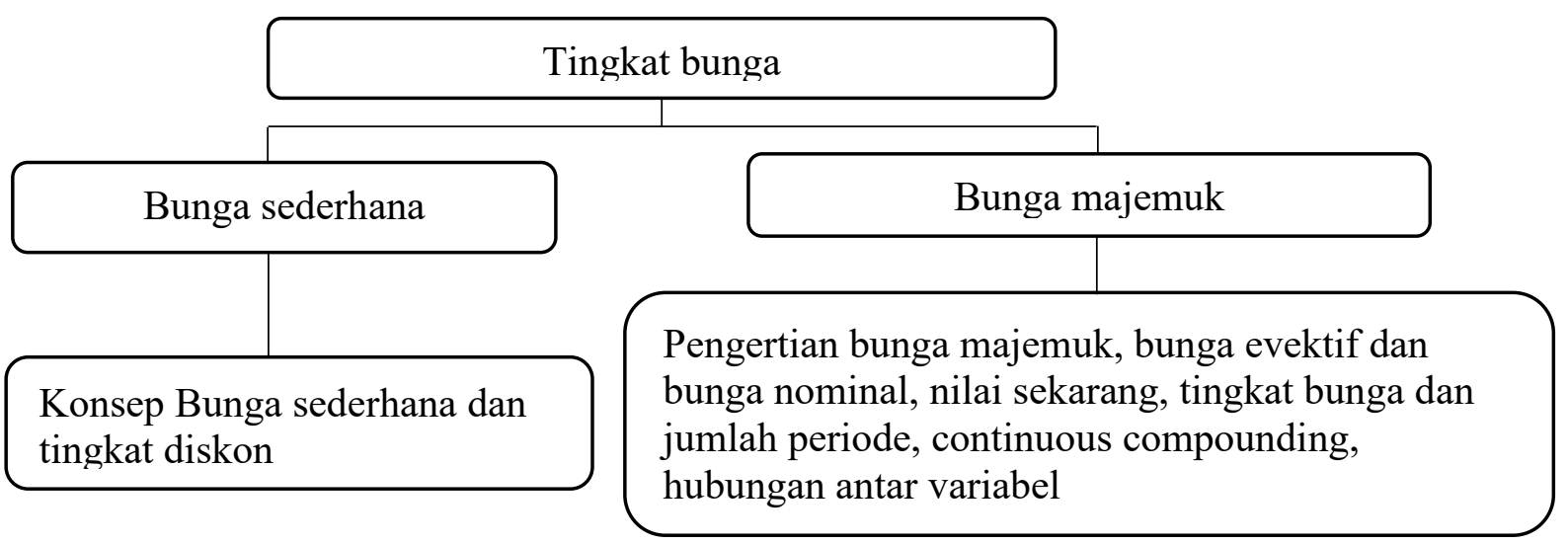

Gambar 2. Bagan Analisis Materi Tingkat Bunga sederhana Dan Tingkat Bunga majemuk

\subsubsection{Analisis tugas}

Berdasarkan hasil analis konsep pada Materi Tingkat Bunga Sederhana Dan Tingkat Bunga Majemuk, maka dapat diidentifikasi tugas-tugas yang dilakukan oleh mahasiswa dalam prose pembelajaran yaitu: 
1. Menentukan nilai diskon sederhana dan majemuk

2. Menghitung nilai sekarang dengan tingkat bunga sederhana

3. Menghitung nilai sekarang dengan tingkat bunga majemuk

4. Menghitung tingkat bunga evektif

5. Menghitung nilai sekarang dengan diskon

\subsubsection{Analisis tujuan pembelajaran}

Berdasarkan analisis materi dan analisis tugas. Indikator pencapaian hasil belajar tersebut diuraikan sebagai berikut:

1. Mahasiswa diharapkan memahami pengertian matematika keuangan

2. Mahasiswa diharapkan mampu menjelaskan tentang matematika keuangan, menerapkannya dengan baik dan benar

3. Mahasiswa diharapkan mampu memahami menghitung tingkat bunga termasuk didalamnya nilai masa depan dan masa sekarang mata uang

\subsection{Tahap Perancangan}

\subsubsection{Pemilihan media}

Media pembelajaran yang diperlukan dalam pelaksanaan pembelajaran materi tingkat bunga dan tingkat bunga nominal disesuaikan dengan analisis materi dan analisis tugas. Berdasarkan analisis tersebut ditetapkan media yang diperlukan dalam pembelajaran untuk materi tingkat bunga sederhana dan tingkat bunga majemuk yaitu zoom dan Laptop.

\subsubsection{Pemilihan format}

Pemilihan format media dimaksudkan untuk mendesain atau merancang isi media pembelajaran yang disesuaikan dengan materi pembelajaran dan Kerangka Kualifikasi Nasional Indonesia (KKNI). Format pengembangan media yang dipilih yaitu konsep yang dapat mencakup semua tujuan pembelajaran dari materi tingkat bunga sederhana dan tingkat bunga majemuk.

\subsubsection{Perancangan awal}

Hasil rancangan awal meliputi rancangan media yang digunakan untuk memperoleh data yang dibutuhkan dalam proses pengembangan. Rancangan media pembelajaran mengacu pada hasil analisis yang telah dilakukan pada tahap define dan fase lain sebelumnya pada tahap perancangan ini. Fase ini akan menghasilkan produk awal yang akan dikembangkan pada tahap pengembangan.

a) Halaman opening/login

Bagian opening ini merupakan bagian pembuka pada media pembelajaran. Pada bagian ini kita bisa login sebagai mahasiswa, dosen dan admin.

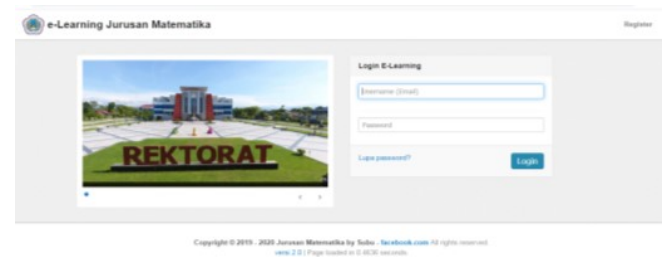

Gambar 3. Halaman opening/login

b) Halaman registrasi

Bagian registrasi ini merupakan bagian pada media pembelajaran dalam bentuk form registrasi. Pada bagian ini kita bisa registrasi sebagai dosen atau mahasiswa dengan mengisi form yang ada. 


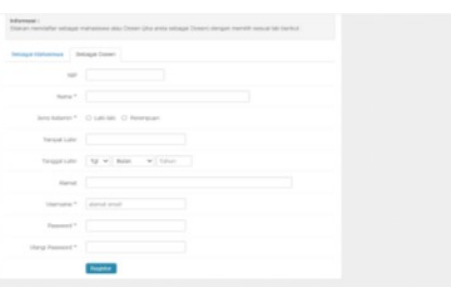

Gambar 4. Halaman registrasi dosen

c) Halaman beranda

Menu ini adalah menu pertama yang menampilkan informasi tentang

- admin: pengumuman informasi, riwayat login,pengaturan matakuliah dan kelas, jumlah dosen dan jumlah mahasiswa

- Dosen: pengumuman informasi, riwayat login

- Mahasiswa: pengumuman informasi, riwayat login,tugas dan materi terbaru.

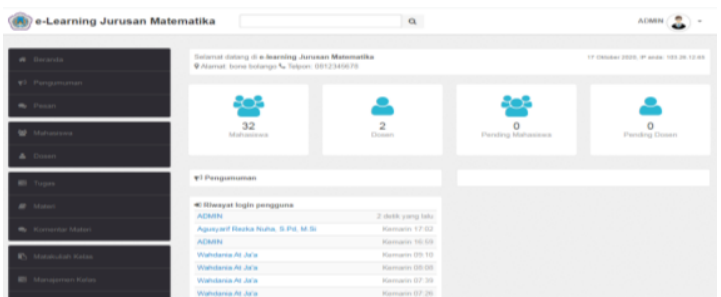

Gambar 5. Beranda admin

d) Halaman profil

Menu ini merupakan menu yang penampilannya hampir sama dengan beranda namun perbedaanya di menu ini kita dapat mengedit atau merubah informasi pada akun pribadi.

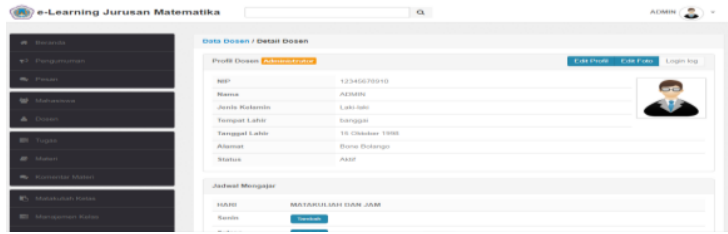

Gambar 6. Halaman profil admin

e) Halaman pengumuman

Menu ini merupakan menu ke dua yang menampilkan pengumuman, di menu ini kita dapat menambahkan pengumuman tapi hanya untuk admin dan dosen.

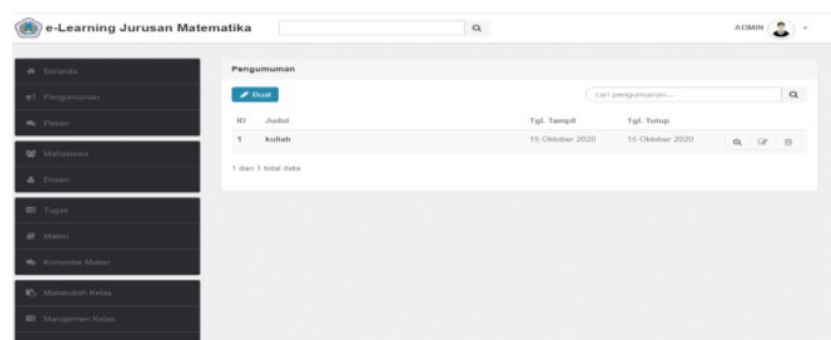

Gambar 7. Halaman pengumuman

f) Halaman pesan

Menu ini merupakan menu ke tiga yang penampilannya hampir sama dengan pengumuman namun perbedaanya di menu ini kita menukar informasi atau memberikan pesan kepada orang tertentu. 


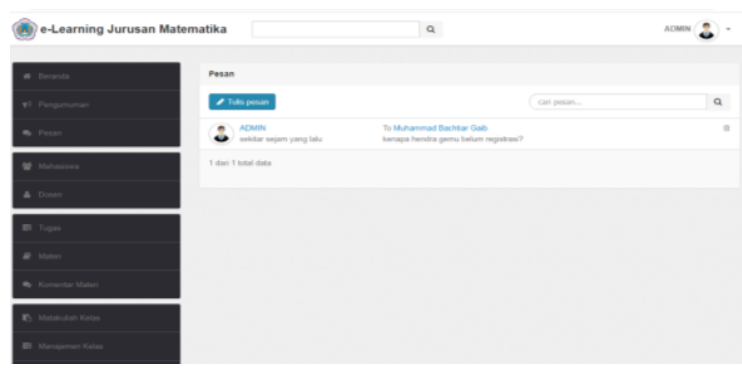

Gambar 8. Halaman pesan

g) Halaman jadwal matakuliah

Menu ini merupakan menu ke empat yang penampilannya hampir sama dengan menu sebelumnya namun perbedaanya di menu ini hanya ada di mahasiswa dan dosen. Dimenu ini kita dapat melihat jadwal matakuliah.

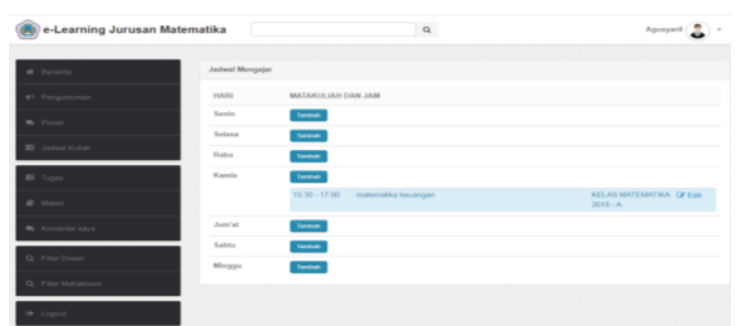

Gambar 9. Halaman dosen mata kuliah

h) Halaman dosen

Menu ini merupakan menu yang penampilannya hampir sama dengan sebelumnya namun perbedaanya di menu ini hanya ada untuk admin. Dimenu ini admin dapat menambahkan, mengaktifkan, dan menonaktifkan dosen.

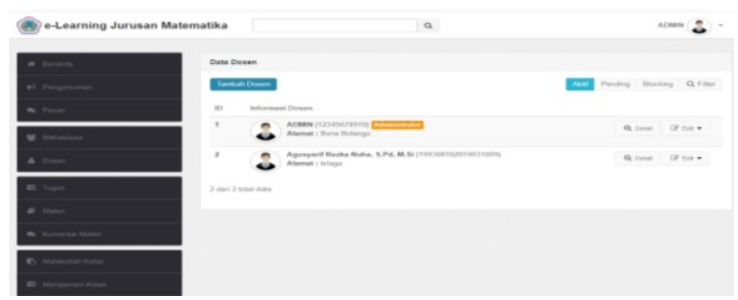

Gambar 10. halaman dosen

i) Halaman mahasiswa

Menu ini merupakan menu yang penampilannya hampir sama dengan sebelumnya namun perbedaanya di menu ini hanya ada untuk admin. Dimenu ini admin dapat menambahkan, mengaktifkan, dan menonaktifkan mahasiswa.

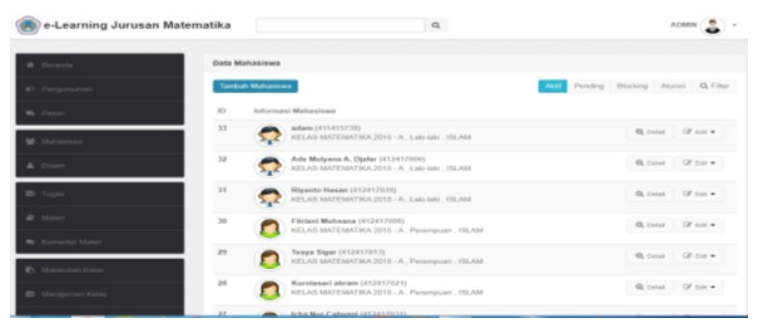

Gambar 11. halaman mahasiswa 


\section{j) Halaman materi}

Menu ini merupakan menu yang penampilannya hampir sama dengan sebelumnya namun perbedaanya di menu ini admin dan dosen bisa menambahkan materi untuk mahasiswa. Sedangkan untuk mahasiswa hanya dapat mendownload dan berkomentar terhadap materi yang ada.

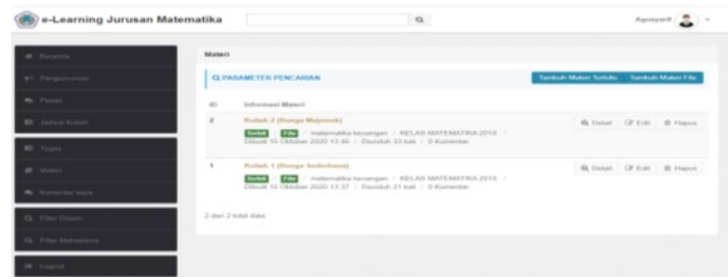

Gambar 12. halaman materi

\section{k) Halaman tugas}

Menu ini merupakan menu yang penampilannya hampir sama dengan sebelumnya namun perbedaanya di menu ini admin dan dosen bisa menambahkan tugas untuk mahasiswa. Sedangkan untuk mahasiswa hanya dapat mengerjakan tugas yang ada.

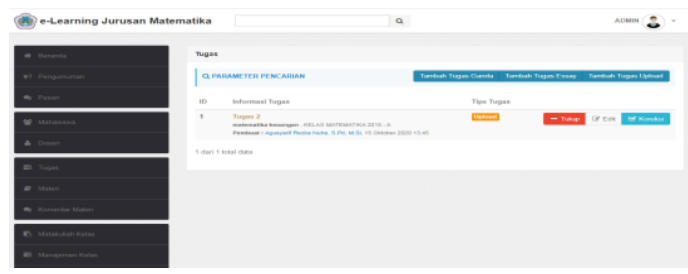

Gambar 13. Tampilan menu awal tugas

1) Halaman komentar

Menu ini berisi komentar dari materi.

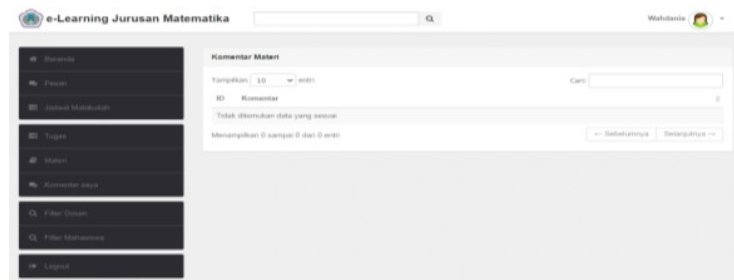

Gambar 14. halaman komentar

m) Halaman filter dosen

Menu ini berisi tentang semua data dosen yang login di web ini.

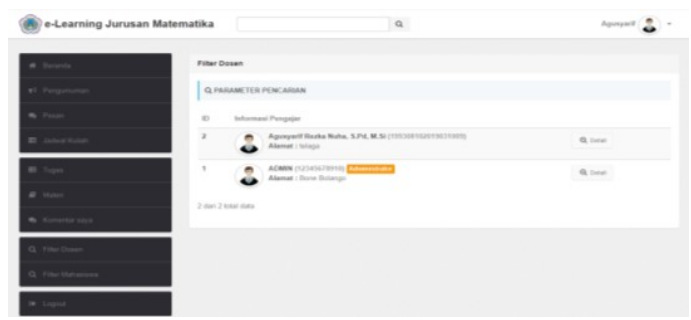

Gambar 15. halaman filter dosen

n) Halaman manajemen matakuliah

Menu ini berisi tentang semua data matakuliah yang ada 


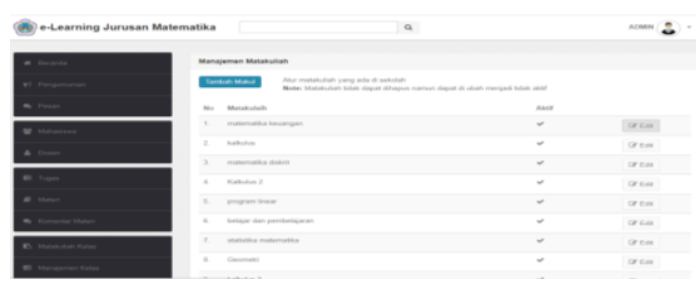

Gambar 16. manajemen matakuliah

o) Halaman manajemen kelas

Menu ini berisi tentang semua data kelas yang ada

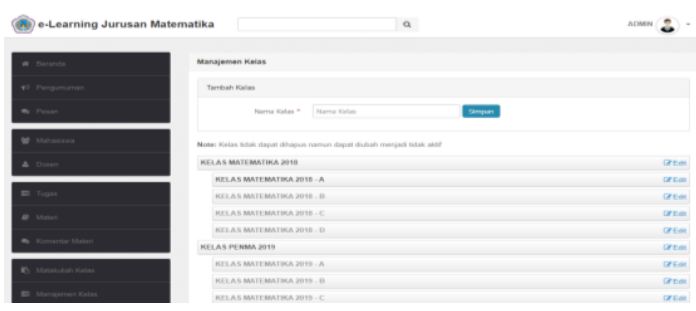

Gambar 17. manajemen kelas

p) Halaman pengerjaan tugas

Sub menu yang menampilkan proses pengerjaan tugas

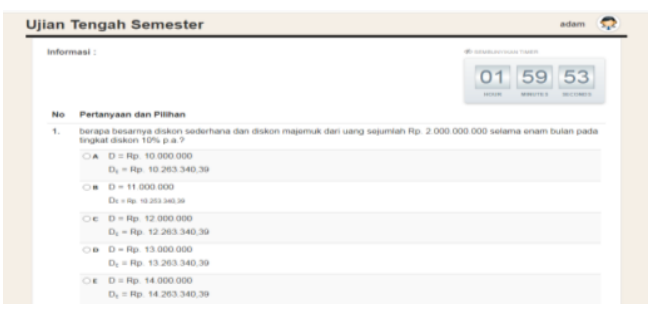

Gambar 18. Tampilan soal pilihan ganda

\subsection{Tahap Pengembangan}

Tahap ini menghasilkan bentuk akhir media pembelajaran setelah melalui revisi berdasarkan masukan dari para ahli dan uji coba.

\subsubsection{Hasil validasi ahli}

Hasil validasi materi dan revisi desain terhadap media pembelajaran berbasis web dengan ratarata adalah 0,85 yaitu termasuk dalam kategori sangat sesuai.

\subsubsection{Uji coba produk dan respon mahasiswa}

Presentase respon mahasiswa pada tiap aspek memperoleh nilai lebih dari 70\%. Hasil respon tiap aspek kemudian dirata-rata dan diperoleh rata-rata presentase total (RT) yaitu 82\%. Berdasarkan tabel kategori respon mahasiswa yang ada pada bab sebelumnya, diperoleh respon mahasiswa berada pada kategori Positif.

\section{Kesimpulan}

Pengembangan media pembelajaran dengan menggunakan model 4-D, dihasilkan media pembelajaran yang baik dan berkualitas, yang ditunjukkan oleh dua indikator, yaitu Hasil validasi dan respon mahasiswa. Validasi ahli terhadap media pembelajaran matematika secara keseluruhan berada pada kategori sangat sesuai dengan nilai 0,86 , sementara respon mahasiswa terhadap media pembelajaran matematika secara keseluruhan berada pada kategori positif dengan persentase $82 \%$. 


\section{Referensi}

[1] Depdiknas, Undang-Undang RI No. 20 Tahun 2003 tentang Sistem Pendidikan Nasional, 2003.

[2] M. Abdurrahman, Pendidikan Bagi Anak Berkesulitan Belajar, Jakarta: Rineka Cipta, 2003.

[3] P. U. Suseno, Y. Ismail, and S. Ismail, "Pengembangan Media Pembelajaran Matematika Video Interaktif berbasis Multimedia,” Jambura J. Math. Educ., vol. 1, no. 2, pp. 59-74, 2020.

[4] R. Rusman, Model-Model Pembelajaran Mengembangkan Profesionalisme Guru, Jakarta: PT. Raja grafindo Persada, 2011.

[5] D. Setyadi dan Q. Qohar, "Pengembangan Media Pembelajaran Matematika Berbasis Web pada Materi Barisan dan Deret," Jurnal Kreano, Vol. 8, No 1, pp. 1-7, 2017.

[6] S. Thiagarajan, D. S. Semmel, dan M. I. Semmel, Instructional Development for Training Teachers of Exceptional Children, A Sourse Book, Blomingtn: Central for Innovation on Teaching Handicappedp, 1974. 